\title{
VÁLLALATI HÁLÓZATOK KOMPATIBILIS IRÁNYÍTÁSA -
}

\section{ÚTMUTATÓ EGY HÁLÓZAT KORSZERÜ IRÁNYÍTÁSÁNAK KIALAKÍTÁSÁHOZ}

A hálózatosodás egyre nagyobb szerepet játszik mind a gazdasági, mind a mindennapi életben. A mind gyorsabban létrejövő́ és mind átfogóbb hálózatoknak sajátos struktúrái alakultak ki. A gazdasági életben a hálózat „középpontjában” a tevékenységet irányító, többnyire nagy- vagy óriásvállalat (az esetek többségében multinacionális korporáció) áll, mint a rendszer integrátora. Köréje szervezódnek a rendszerben a partnerek. Ezek két lehetséges pozícióban járulhatnak hozzá a hálózat múködéséhez: vagy bolygóvállalatként kizárólag az integrátor számára végzik tevékenységüket, vagy vevókörös vállalatként az integrátoron kívül más vállalatokat is kiszolgálnak. Végül kialakultak olyan hálózatok is, amelyekben mindkét partnertípus jelen van: ezek a vegyes szerkezetü hálózatok. Az integrátor vállalat vezetésének mindig mérlegelnie kell, hogy egy tervezett hálózat szerkezete, vagyis a lehetséges partnerpozíciók milyen elônyökkel és hátrányokkal rendelkeznek, amikor dönt a hálózat kiépítéséról. Ehhez ad segítséget a szerzố.

\section{Kulcsszavak: hálózatok, stratégia, irányítás}

A múszaki fejlődést három új sajátosság jellemzi korunkban: üteme egyre jobban gyorsul, mind több a fejlesztésekben a hosszadalmas kísérletezést követelő „trial and error” kutatás aránya, s végül még a pillanatnyi felfedezés, az újdonságra való „heuréka-rátalálás” termékként vagy technológiaként való megvalósítása is mind összetettebb feladattá vált. Márpedig ezeknek súlyos a következménye: a múszaki fejlődéssel való lépéstartás a vállalatok versenyben maradásának múlhatatlan feltétele lett, egyre inkább meghatározó és egyre inkább megnyugtató versenyelőny számukra, ha be tudnak sorolni a fejlesztés mind ,,arisztokratikusabb" élvonalába, és nem utolsósorban egyre nagyobb fejlesztési forrásokra van szükségük ahhoz, hogy növeljék versenyelőnyüket, vagy legalább megtartsák korábbi versenyképességüket.

A vállalatoknak három kézenfekvő lehetôségük van arra, hogy növeljék fejlesztési forrásaikat. Az egyik megoldás, hogy egyre szélesebb körre terjesztik ki tevékenységüket a globális színtéren, így módjuk van rá, hogy felgyorsítsák kutatás-fejlesztési befektetéseik megtérülését, ezzel hamarabb jussanak újabb fejlesztési forrásokhoz, illetve növeljék ezek volumenét a kritikus időszakban. A másik megoldás: szúkítik tevékenységük tartalmát, olyan fejlesztési és múködési részterületekre összpontosítanak, amelyeken nagy versenyelőny kínálkozik számukra, vagyis kihasználják a „magkompetencia”, a „core competency” lehetőségeit. Ez az összpontosítás azonban csak úgy jöhet létre, ha számos korábbi tevékenységüket „,kiszervezik” más vállalatokhoz (ez a közismert „outsourcing”). A mind élesebb verseny pedig azt követeli meg, hogy a kiszervezett tevékenységeket végzók már ne csupán laza kapcsolatban álljanak az outsourcingot végrehajtó vállalattal, hanem azzal olyan hálózatot alkossanak, amelynek mind szervesebb (konzisztensebb) a múködése és irányítása. A jól összehangolt múködés és irányítás ugyanis újabb versenyelőnyt ad a hálózat valamennyi szereplője számára.

A vállalatok hálózatba tömörülése egyre inkább tért hódít napjainkban. Az összehangolt szakosodás ugyanis javítja a folyamatok, a termékek és szolgáltatások minőségét, növeli az egyes vállalatok nagyságrendi megtakarításait, ami költségelőny az egész hálózat számára, a kisebb vállalatok bevonása többnyire csökkenti 
a termelés/szolgáltatás általános költségeit, ami újabb költségelőny, a szúkebb tevékenységprofilok elősegítik a vállalati folyamatok szervezettségének javítását, valamint felgyorsítják a vállalatok alkalmazkodását az új piaci lehetôségekhez és fenyegetésekhez, s a jól múködő hálózat végül összességében fokozza a rendszer egészének rugalmasságát, alkalmazkodóképességét. Mindennek hatására az utóbbi idôszakban nagyobb ütemben bóvült a hálózatok versenye, mint a hálózatba be nem épült vállalatoké, bár fékezte a hálózatosodást egy ellentétes törekvés, nevezetesen a vállalati felvásárlás és összeolvadás (a „Merger and Aquisition”, az $\mathrm{M}+\mathrm{A}$ ), mint a fejlesztési források bővítésének harmadik nagy lehetősége. (A kiszervezés és az M+A ellentétes ugyan, de nem zárja ki egymást: az M+A nem akadályozza meg a kiszervezést, példák erre korunk autóipari mamutvállalatai, amelyek M+A-kkal egyre nagyobbra nônek, ám ugyanekkor egyre szélesebb körú kiszervezést valósítanak meg.)

A mind gyorsabban létrejövő és mind átfogóbb hálózatoknak sajátos struktúrái alakultak ki. A hálózat „középpontjában” a tevékenységet irányító, többnyire nagy- vagy óriásvállalat (az esetek többségében multinacionális korporáció) áll, mint a rendszer integrátora. Köréje szerveződnek a rendszerben a partnerek. Ezek két lehetséges pozícióban járulhatnak hozzá a hálózat múködéséhez: vagy bolygóvállalatként kizárólag az integrátor számára végzik tevékenységüket, vagy vevókörös vállalatként az integrátoron kívül más vállalatokat is kiszolgálnak. Végül kialakultak olyan hálózatok is, amelyekben mindkét partnertípus jelen van: ezek a vegyes szerkezetú hálózatok. Mind a bolygó- és vevőkörös vállalati partnerekkel kialakított, mind a vegyes szerkezetú hálózatoknak megvannak a sajátos előnyeik és fogyatékosságaik. Ezek tartalma éppúgy függ a múszaki fejlôdés sajátosságaitól, mint a piacok jellegzetességeitôl, a vállalat iparágától, fejlesztési, termelési, értékesítési és gazdálkodási rendszerétól vagy a számításba jövő partnerek együttmúködési készségétôl és képességétől. Az integrátor vállalat vezetésének tehát mindig ezek figyelembevételével kell mérlegelnie egy tervezett hálózat szerkezetének, vagyis a lehetséges partnerpozícióknak az elônyeit és fogyatékosságait, amikor dönt a hálózat kiépítéséról.

Kézenfekvő azonban, hogy bármilyen szerkezetben jöjjön is létre egy hálózat, számottevóen megnöveli múködésének hatékonyságát - sốt, ezt sokszor egyenesen multiplikálja -, ha létrejön irányításában a kompatibilis irányítás. Ez azt követeli meg, hogy az integrátornak és partnervállalatainak sokszor szükségszerúen és akár jelentősen is különbözó irányítási rendszerei (amelyek sajátosságai nagyon is indokoltak az eltérő vállalati nagyságrendek és tevékenységi körök miatt) zavartalanul illeszkedjenek egymáshoz. A kompatibilis irányítás ugyanis felgyorsítja a tervezési és a döntési folyamatokat, és csökkenti a kockázatukat, lerövidíti a végrehajtási folyamatokat és megkönnyíti azok ellenőrzését, szükség esetén lehetôvé teszi a tervek végrehajtásának módosítását valamennyi feltétel és következmény mérlegelésével, végül, de nem utolsósorban, fokozza a közös programokban részt vevô vállalatok vezetôinek azonosulását a közösen kitûzött célokkal és azok tervszerú valóra váltásával.

Az ilyen kompatibilis irányításnak három nagy területe van: az integrátor és a partnervállalatok összehangolt üzleti stratégiájának a kialakítása, az egyeztetett kutatás-fejlesztés létrehozása (ami korunkban - mint említettük - a vállalati versenyképesség mind meghatározóbb tényezője lett), valamint a koordinált operatív irányítás, amelyik lehetôvé teszi a hálózati rendszer optimumának megvalósítását, szemben a csak lokális (tehát csupán vállalati) eredménymaximumokat, illetve veszteségminimumokat érvényesítő törekvésekkel.

A hálózati struktúra felvázolt alapeseteit és a kompatibilis irányítás említett fố területeit foglalja egységbe az 1. táblázat, amelyben a kilenc érdemi mezó tartalma gondolatmenetünk következó témáit és azok sorrendjét is jelzi.

1. táblázat

A hálózati struktúra és

a kompatibilis irányítás kilenc fő témaköre

\begin{tabular}{|l|c|c|c|}
\hline \multirow{2}{*}{$\begin{array}{l}\text { A hálózati } \\
\text { struktúra alap- } \\
\text { esetei }\end{array}$} & \multicolumn{3}{|c|}{$\begin{array}{c}\text { A kompatibilis irányítás } \\
\text { fó területei: }\end{array}$} \\
\cline { 2 - 4 } & $\begin{array}{c}\text { üzleti } \\
\text { stratégia }\end{array}$ & $\begin{array}{c}\text { kutatás- } \\
\text { fejlesztés }\end{array}$ & $\begin{array}{c}\text { operatív } \\
\text { irányítás }\end{array}$ \\
\hline $\begin{array}{l}\text { Bolygóvállalati } \\
\text { kapcsolat (B) }\end{array}$ & $1 . \mathrm{B}_{\text {strat }}$ & $2 . \mathrm{B}_{(\mathrm{K}+\mathrm{F})}$ & 3 . $_{\text {Bopir }}$ \\
\hline $\begin{array}{l}\text { Vevőkörös vállalati } \\
\text { kapcsolat (V) }\end{array}$ & $4 . \mathrm{V}_{\text {strat }}$ & $5 . \mathrm{V}_{(\mathrm{K}+\mathrm{F})}$ & $6 \cdot \cdot_{\mathrm{Vopir}}$ \\
\hline $\begin{array}{l}\text { Vegyes szerkezetú } \\
\text { rendszer }(\mathrm{VR})\end{array}$ & $7 . \mathrm{VR}_{\text {strat }}$ & $8 . \mathrm{VR}_{(\mathrm{K}+\mathrm{F})}$ & $9 . \mathrm{V}_{\text {Ropir }}$ \\
\hline
\end{tabular}

\section{Kompatibilis irányítás bolygóvállalati kapcsolatban}

\section{Összehangolt üzleti stratégia}

Sajátos feladatsor teljesítésével valósulhat meg az a kompatibilis irányítás, amelyik az integrátornak és bolygóvállalatának összehangolt üzleti stratégiáját $\left(\mathrm{B}_{\text {strat }}\right)$ hozza létre. A feladatsor hét, a végsố sikert meghatározó részfeladata - egy már korábban kialakult, de még nem kompatibilis irányítással múködő bolygóvállalati kapcsolat esetében - a következő: 


\section{Vállalatátvilágítás közös teammel}

Ehhez az integrátor és minden bolygóvállalata létrehoz egy olyan közös munkacsoportot (akár szakterületi témánként változó személyi összetételben), amelyik újra számba veszi a két vállalat eróforrásait, múködési folyamatait és irányítási rendszereit, beleértve ez utóbbiba a vállalat alapértékeit éppúgy, mint kialakult arculatát vagy vezetési koncepcióit és technikáit. Ezt követốen mérlegeli ezek elônyeit és hátrányos jellemzőit, elsősorban a bolygóvállalati kapcsolat rugalmassága szempontjából. (Az együttmúködés „hagyományos” értékelése ugyanis feltételezésünk szerint már korábban megtörtént.) Stratégiaváltás esetén ugyanis számos bolygóvállalati kapcsolat bukik meg olyan tényezókön, mint a két vállalat alapvetôen különbözô értékrendje vagy eltérô vezetési koncepciója, stílusa. A munkacsoport ennek keretében meghatároz olyan kritikus értékeket (többnyire múködési területenként, például a termelókapacitás-bővítés vagy a beruházási igény), amelyek már megakadályoznák a stratégiaváltást.

\section{Környezetfigyelô térkép szerkesztése}

Az üzleti stratégia témakörében a kompatibilis irányítás egyik alapvetố kritériuma, hogy az integrátor és bolygóvállalatai pontosan megszerkesztett és egyeztetett „térkép” szerint figyeljék: bekövetkeznek-e környezetükben olyan változások, amelyek indokolják a stratégia módosítását. Egy ilyen környezetfigyelő térkép alapján többnyire az integrátor feladata:

1. A múszaki fejlődés irányzatának és új eredményeinek feltárása a végtermék esetében (beleértve a trendeket az anyagok, termékek, gyártástechnológiák, szervizkövetelmények stb. esetében).

2. A végtermékpiacok alakulásának felmérése és prognózisa (beleértve a végtermékek vásárlóit, a potenciális vevớket, a meglévő és a várható versenytársak kínálatát és üzletvitelét stb.).

3. A piac alakulását befolyásoló országos, regionális és globális gazdasági háttér figyelése (ami többnyire az erre szakosodott intézetek általános információinak értelmezését követeli meg az adott piac szempontjából).

A bolygóvállalatok figyelési területe általában:

- A múszaki fejlődés trendjének és eredményeinek számbavétele saját múködési területükön (szintén a már említett tényezók tekintetében).

- A potenciális versenytárs bolygóvállalatok erôs oldalainak és gyenge pontjainak feltárása, ami segítségükre lehet, hogy az integrátor ne bontsa fel kapcsolatukat egy új partner hosszú távon kedvezóbb ajánlata miatt.

- Az integrátor pozíciójának és pozícióváltozásának értékelése mind a múszaki fejlesztésben, mind a pia- ci jelenlétben. (Hiszen még egy pozíciógyengülés is végzetes lehet a bolygóvállalat számára!)

\section{A folyamatos párbeszéd megszervezése}

A környezetfigyeló térkép alapján folyamatosan beszerzett információk rendszeres cseréje az integrátor és bolygóvállalata között a kompatibilis irányítás sine qua nonja. Egy ilyen párbeszéd lényeges követelménye, hogy ne csupán a környezet lehetôségeiról és fenyegetéseiról tájékoztasson: minden esetben értelmezzék is ezeket mind az integrátor, mind a bolygóvállalat szempontjából. A tájékoztatás tartalmát és folyamatosságát azonban aligha tudja ellenórizni a partner, hiszen - az egyeztetett térkép alapján - nincs az ehhez szükséges információk birtokában. Ezért a folyamatos párbeszéd alapja csak a kölcsönös bizalom lehet, amelyet a jelzett események bekövetkezése erősíthet. Magát a párbeszédet szintén a két vállalat erre szervezett közös, de többnyire csak két-három fôs munkacsoportjára célszerú rábízni: az ebben részt vevớk továbbíthatják aztán az információkat a vállalatok vezetôinek, stratégiai tervezô szervezetüknek vagy a témában illetékes (például funkcionális) vezetőinek. (Ez a megoldás persze nem zárja ki, hogy „vészhelyzetben”, vagy ha jelentős új üzleti lehetôség nyílik meg a környezetben, ne rögtön a vállalatok csúcsvezetôi között jöjjön létre a párbeszéd.)

\section{Folyamatos múködési tájékoztatás megszervezése}

Kompatibilis irányításban az integrátor és bolygóvállalata a múködésról is folyamatosan informálják egymást. A múködésben bekövetkezô nagyobb zavarok ugyanis megkövetelhetik az üzleti stratégia módosítását. A tájékoztatás az integrátor esetében elsősorban rendelés- és készletállományáról, termelésprogramozásáról, bolygóvállalatának beszállításait, szolgáltatásait érintő értékesítéséról, gazdálkodásának átfogó eredményeiról, valamint a bolygóvállalat tevékenységével kapcsolatos elszámolásairól szól. A bolygóvállalatnak ezzel szemben múködésének szinte valamennyi folyamatáról és eredményéról tájékoztatnia kell az integrátort. Ez a tartalmában és súlyában felemás informálás a bolygóvállalati rendszer velejárója: a vállalati múködés nagyobb biztonságának ára a nagyobb kiszolgáltatottság. S az ilyen múködési tájékoztatás létrehozásában kap nagy szerepet a kontrolling: a saját vállalat vezetóje számára összegyújjtött és feldolgozott kontrollingadatok ugyanis egyszerúen átáramolhatnak a partner kontrollingszervezetéhez. Az információk értékelésekor pedig - üzleti stratégiai szempontból - a jól ismert „Management by Exceptions" technikát célszerú alkalmazni: a rendszernek csak azokat az információkat szabad továbbítania a stratégiáért felelősöknek, amelyek meghaladnak egy előre megszabott alsó vagy felsô küszöbértéket. 


\section{A stratégiai variánsok egyeztetése}

Korunk mind turbulensebb változásai közepette már nem elég egyetlen (optimális) stratégiát megtervezni. A külsô (környezeti) vagy a belsô (vállalati) feltételek gyors változása ugyanis kikényszerítheti az elfogadott stratégia módosítását, sốt az olykor paradigmaváltással járó stratégiaváltást is. Ha nem állnak ilyenkor - legalább „félkész állapotban” - stratégiai változatok egy vállalat rendelkezésére, akkor könnyen kerülhet sor a „management in crisis” kapkodására, ami végül válsághelyzetet okozhat és „crisis management”-et, válságmenedzselést kényszeríthet ki. Kompatibilis irányítás keretében tehát egyeztetni kell a stratégiai variánsokra vonatkozó integrátori és bolygóvállalati elképzeléseket. S nem ritka, hogy a bolygóvállalati variánsok ,döbbentik rá" az integrátor üzleti stratégiáinak tervezóit arra, hogy újabb variánssal egészítsék ki saját változataikat. Mindezzel kapcsolatban azonban meg kell jegyezni: önmagában a stratégiai variánsok és bevezetésük feltételeinek kimunkálása még kevés. Az egyre nehezebben kiszámítható külsố és belsố változások miatt a variánsok megtervezésével egy idóben mind az integrátor, mind a bolygóvállalat már említett rugalmasságának növelését is célul kell kitüzni.

\section{Egyeztetés a stratégia néhány más kritikus jellemzójéról}

Az üzleti stratégia egyeztetett kialakítása azonban felvet néhány sajátos kérdést is: 1 . Minden „stratégiai gondolkozás" - a környezeti feltételek számbavétele mellett - négy belső (vállalati) tényezố együttes mérlegelését követeli meg: a ráfordítás és az eredmény volumenének, a kockázat mértékének és az esetleges pályamódosítás, pályaváltás „ráfordításáldozatának” értékelését. 2. A stratégia időtávját mindig az integrátor határozza meg (elsôsorban a múszaki fejlődés ütemét és a piaci előrejelzésnek az idôtávval fokozódó bizonytalanságát mérlegelve). A bolygóvállalatnak lehetôség szerint igazodnia kell ehhez az idôtávhoz, de adott esetben jeleznie kell ezen belül azt a határt, amelyen túl prognózisának bizonytalansága már meghaladja a kritikus értéket. 3. A bolygóvállalatnak azt is hozzá kell füznie az integrátorral közösen kimunkált stratégiai variánsokhoz, hogy ezek megvalósítása milyen és mekkora „ráfordítás-áldozatokat” követelne meg, s ezekhez milyen mértékben rendelkezik saját eróforrásokkal. 4. Minden stratégia tartalmaz olyan elemeket, amelyek joggal minősíthetók üzleti titoknak. Az integrátornak és a bolygóvállalat vezetójének közösen kell meghúznia azt a határt, amelyen már nem szivároghatnak át információk sem a két vállalat szervezetébe, sem a környezet szereplóihez. Ennek betartása a vállalatok közös érdeke. Könnyen bekövetkezhet ugyanis akár a hálózat egészének a felbomlása, ha kiderül, hogy „lyukacsos” az üzleti titkokat védố háló .

\section{A bolygóvállalat stratégiai ,lépéstartásának” megitélése}

Egy bolygóvállalat többnyire jóval kisebb eróforrástömeg fölött rendelkezik, mint integrátora. Ezért könynyen előfordulhat, hogy lemarad egy olyan stratégiai cél megvalósításában, amelyik a meglévőnél nagyobb erőforrástömeget igényel. Márpedig ez mind alapvetốbb kérdése lesz a bolygóvállalatok kiválasztásának: az integrátor számára csökken a bolygóvállalat-jelölt által kínált pillanatnyi elóny jelentôsége, és megnố annak a súlya, hogy várhatóan lépést tud-e majd tartani az integrátor által tervezett stratégiai fejlesztésekkel. Ezért szükséges, hogy a kompatibilis irányítás kiterjedjen a hosszú távú fejlesztési célok eléréséhez szükséges erőforrások - és elsősorban a bolygóvállalat ezt szolgáló erőforrástömegének - számbavételére is. Ebból a szempontból a legkritikusabb eróforrásfajta az, amelyik a kutatásfejlesztéshez szükséges. S ez mindinkább igényli nem csupán a technikai és a financiális, hanem a tovább- és átképzéssel szintén megújított humán eróforrást is.

\section{A kutatás-fejlesztés $(K+F)$ kompatibilis irányítása}

$\mathrm{Az}$ integrátor vállalat és bolygóvállalatai között a kutatás-fejlesztés $(\mathrm{K}+\mathrm{F})$ kompatibilis irányítása - az 1 . táblázat jelölése szerint $a B_{(K+F)}-a$ hálózat sikerének másik és szintén alapvetô kritériuma. A K+F hosszú távú céljai szerepelnek a stratégiai tervekben. Ezeknek a céloknak a valóra váltása azonban három sajátos kérdést is felvet.

- A K+F első és sokszor meghatározó feltétele a finanszírozás, méghozzá fóként a bolygóvállalat esetében. A kis- és középvállalatok ugyanis többnyire jóval szorosabb gazdálkodással múködnek, mint a nagy- és óriásvállalatok, s ezért kevésbé tudnak alapokat képezni számottevő fejlesztési beruházásokra. Ilyenekre hiteleket is nehezebben vagy rosszabb feltételekkel kaphatnak a pénzintézetektól, különösen akkor, ha a tervezett fejlesztés eredménye csak hoszszabb távon valósul meg, és/vagy várhatóan erôs piaci versenyben való helytállás függvénye lesz. Ezért vár két feladat az integrátorra, ha azt kívánja, hogy bolygóvállalata jelentôs kutatás-fejlesztéseivel is lépést tartson:

- folyamatosan figyelemmel kell kísérnie, hogy partnere (lehetőségei szerint) képez-e ígéretes fejlesztési alapot,

- s ha erre nem képes, a banki ajánlatoknál kedvezóbb feltételekkel kell segítenie a létrehozott kisebb alap kiegészítését. 
$\mathrm{Az}$ integrátor a bolygóvállalat mérlegének és eredménykimutatásának adataiból tudja figyelemmel kísérni a létrejövố fejlesztési alapot, s erre a tájékozódásra - a kkv-k számára kidolgozott informatikai rendszerek segítségével - akár negyedévenként is sor kerülhet. A kedvezóbb hitel mértékét pedig olyan célfeltételekhez is kötheti az integrátor, mint a beruházás költségmegtakarítása, időigényének csökkentése vagy komplex „,beüzemelése”. (Ezek a kritériumok egyúttal indokolják, hogy miért nem helyes, ha az integrátor vissza nem térítendô beruházási támogatást ad: ez könnyen elkényelmesíti a bolygóvállalatot.) A finanszírozás kérdése azonban megfordítva is felvetốdik: a bolygóvállalatnak is érzékelnie kell, hogy az integrátor rendelkezik-e a versenyképessége fenntartásához szükséges fejlesztési forrásokkal? Ezt - a különböző nagyságrendek miatt - úgy érzékelheti a bolygóvállalat vezetése, hogy az integrátor éves mérlegének és eredménykimutatásának, valamint a piaci versenyben elfoglalt múszaki fejlesztési és piaci pozíciójának öszszevetéséból vonja le következtetését. ( $\mathrm{S}$ ha az eredmény negatív, a bolygóvállalat elkezdheti saját jövőjének a biztosítását akár egy másik integrátornak tett ajánlattal, akár önálló piacra lépéssel.)

- A K+F másik és a gyorsuló múszaki fejlődés közepette mind „fogasabb” kérdése az azt létrehozó és/vagy múködtetố tudás megszerzése. A múszaki fejlődés élvonalához tartozó integrátor vezetése számára ez azt a feladatot jelöli ki, hogy jövóbeli versenyképessége (magkompetenciája) szempontjából jól kell felismernie a tudás fejlődésének irányát és ütemét. A múszaki fejlődést csak követố integrátor vezetésének viszont úgy kell meghatároznia a követés távolságát, hogy az illeszkedjék a kevésbé igényes és kisebb fizetőképességgel rendelkező piacok keresletéhez. (Az élvonalbeli integrátor „figyelő szemét” tehát elsôsorban a múszaki trendre, a követô integrátor pedig a jövedelmezőséget kínáló piacokra veti.) S mindebból különösebb mérlegelés nélkül következik már az élvonalbeli vagy a követô integrátor bolygóvállalatának tudást bóvító vagy új tudást megszerző feladata is. Ehhez az új tudás megszerzésének négy formája létezik:

1. Az új tudás létrehozása a vállalat szervezetében. (Erre fóként az integrátornak, s nem bolygóvállalatának van lehetősége, hiszen egy saját kutatóbázis kiépítése igencsak költségigényes.)

2. Az új tudás megvásárlása, például megszerzése egy annak létrehozására szakosodott intézettól.

3. Az új tudás megszerzése szervezett képzés segítségével, például szaktanfolyamon vagy egyetemi, főiskolai képzés keretében.
4. Az új tudás létrehozása a munkatársak irányított önképzésének eredményeként. (Ezzel kapcsolatban érdemes megjegyezni: az irányított önképzés alapvető feltétele a munkatársak ezt ambicionáló olyan karrierterve, amelyik célkitúzéseiben illeszkedik a vállalat $\mathrm{K}+\mathrm{F}$ feladataihoz.)

A kompatibilis irányítás azt követeli meg, hogy elóbb az integrátor és a bolygóvállalat humáneróforrás-menedzsmentje egyetlen hosszú távú programban egyeztesse mind az új tudás megvásárlását, mind megszerzését szervezett képzéssel vagy önképzéssel, majd a két vállalat legfelsố vezetése idôszakosan és szigorúan ellenôrizze ennek végrehajtását. Erre azért van szükség, mert a stratégiai $\mathrm{K}+\mathrm{F}$ megvalósításának leginkább időigényes feladata a humán erőforrás felkészítése az új feladatok ellátására, vagyis az új tudás létrehozása.

- A K+F harmadik jelentős kérdése az a nem financiális támogatás, amelyet az integrátor nyújthat bolygóvállalata számára, hogy az könnyebben tudjon lépést tartani a fejlesztéseivel. Számos ilyen támogatási forma létezik az integrátor szakértóinek egy-egy alkalomra szóló vagy tartós rendelkezésre bocsátásától az ingyenes vagy kedvezményes knowhow-átadások révén a bolygóvállalati munkatársak akár hosszabb idôre szóló fogadásáig és továbbképzéséig az integrátornál. Mindezzel kapcsolatban két sajátosságot érdemes kiemelni: a nagylelkú támogatás többnyire nagyobb hasznot hoz (és nem csupán a hálózat egészének, hanem az integrátornak is), mint amennyi áldozattal jár, és a támogatás nem csupán szakmai segítséget ad, hanem mintegy összecsiszolja az integrátor és a bolygóvállalat kultúráját is. És egy ilyen egységes hálózati kultúra kialakítása már nem „avatatlan széplelkek” tanácsa a biznisz kókemény músszaki-gazdasági feltételei közepette, hanem alapvetô hozzájárulás - még egy kegyetlen versenyben is - a sikeres kompatibilis irányítás létrejöttéhez.

\section{Operatív irányítás}

A harmadik kérdéskör integrátor és bolygóvállalat kompatibilis irányításában a két vállalat napi múködésének operatív irányítása: az 1. táblázat jelölése szerint a $\mathrm{B}_{\text {opir }}$ tevékenység. Ennek feladatait, folyamatait és az összehangolt irányításért felelős vállalati szervezetek kapcsolatának formáit foglalják össze a következők.

Az operatív irányítás fó feladatai természetesen a vállalatok iparágától és tevékenységétől (profiljától) függnek. Az egyik legsokrétúbb egy olyan vállalat feladatköre, amelyik számos terméket állít elő és értékesít. Példaként vegyük sorra témánk szempontjából az operatív irányítás legfontosabb feladatait egy ilyen vállalatban: 
1. A „marketing I.” feladata az operatív irányításban, hogy folyamatosan figyelemmel kísérje a piaci lehetôségeket és korlátokat a termékfejlesztés, a gyártás és a jövedelmező értékesítés szempontjából.

2. A kutatás és fejlesztés operatív irányításának nem csupán a $\mathrm{K}+\mathrm{F}$ tervek ütemes végrehajtását kell ellenőriznie, hanem azt is, hogy nem következtek-e be elôre nem látott események a felhasználható anyagok, a gyártmányok és a technológiák területén.

3. A beszerzésnek sem csupán a termelés és értékesítés követelményeihez, valamint a készletek összetételéhez kell igazodnia, azt is figyelemmel kell kísérnie, hogy nem jelenik-e meg az eddiginél kedvezóbb beszerzési forrás a kínálat piacán.

4. A beszerzésnek mint megrendelésnek létre kell hoznia az ehhez szükséges hatékony technikai megoldást.

5. A termelésirányítás fő feladata a komplex munkafolyamatok fázisainak összehangolása és a termelés piaci igényekhez alkalmazkodó hatékony átállításainak a megszervezése.

6. A készletgazdálkodásnak úgy kell folyamatosan kielégítenie a termelés igényeit, hogy közben minimálisra csökkentse a készletezés költségeit.

7. A ,marketing II.” végzi a gyártott termékek értékesítését az ezt segítô reklám- és promóciós tevékenységekkel.

8. Az értékesített termékek számlázásának alapvetô tennivalója a teljesítés elszámolásának technikai lebonyolítása.

9. A humán erőforrás operatív irányításának fớként felvételi-elbocsátási, munkaerô-nyilvántartási, ösztönzési rendszerfejlesztô és képzési-továbbképzési feladatai vannak.

10. A számvitelnek folyamatosan és pontosan kell végigkísérnie a vállalat valamennyi múködési folyamatának pénzben mért ráfordításait és hozamait.

11. A pénz- és eszközgazdálkodás tartja számon a vállalat vagyonát és szervezi a vagyon szerkezetének alakulását a vagyongyarapodás érdekében.

12. A jelentősebb beruházások szervezésének kettős célja a szükséges források volumenének, valamint megvalósulásuk idôigényének a minimálása.

13. A kontrolling úgy ellenőrzi a vállalat múködésének alapvető folyamatait, hogy ezekról lehetóleg teljes körú áttekintést adjon a vállalat vezetésének.

14. A stratégiai tervezés kíséri figyelemmel, hogy nem következtek-e be olyan változások a verseny-, valamint a háttérkörnyezetben, amelyek indokolják a stratégia módosítását vagy új stratégia megfogalmazását.
15. A vállalat vezetése felügyeli, hogy hatékonyan szolgálja-e az operatív irányítás a stratégiai célokat, hogy szükség esetén módosíthassa az irányítás feladatait, szervezetét és technikáját.

A felsoroltak közül minden feladatot el kell látnia egy integrátor vállalatnak. Bolygóvállalatának tevékenységében azonban felesleges a „marketing I.” és a „marketing II.” feladat elvégzése, hiszen megrendeléseit az integrátortól kapja, s ez át is veszi értékesítésre a gyártott anyagokat, alkatrészeket vagy részegységeket. A bolygóvállalati hálózatban vannak tehát csak az egyik résztvevő által végzett kizárólagos tevékenységek. Vannak olyan tevékenységek is, amelyek azonos szerkezetet és múködést igényelnek a hálózat egészében: ilyen a megrendelés és a számlázás, a számvitel, a pénz- és eszközgazdálkodás, a kontrolling, valamint a stratégia-felülvizsgálat tevékenysége. Ezek tehát a hálózat egészében egységes tevékenységek. Az utóbbi hét tevékenységen kívül marad még nyolc felsorolt feladat. Ezek elvégzéséhez az integrátornál részletesen kibontott, vagyis differenciált, a bolygóvállalatnál pedig egyszerüsített folyamatokra és tevékenységekre van szükség. Ez a kétféle tevékenység jól érzékelhetô abban, ahogy a számítástechnika szolgálhatja a felsorolt operatív irányítási feladatok elvégzését: a nagy- és óriásvállalatok múködésének támogatására kimunkált modelleket úgy kell egyszerúsítenie a hálózataikba beépült kkv-k számára, hogy ezek modelljei illeszkedjenek nagy partnervállalataik modelljeihez, s így információik kölcsönösen értelmezhetók, vagyis kompatibilisek legyenek.

Az operatív irányítás másik kérdése: az integrátornak és bolygóvállalatának milyen szervezeti kapcsolata szükséges ahhoz, hogy az irányítás hatékony legyen? Ilyen irányítás valósulhat meg a „két csatornatípus” kialakításával. Ezek közül egyik a szakmaközi csatornatípus, amelyik az integrátor és a bolygóvállalat szakterületi felelôsei között közvetlen kapcsolatot hoz létre. (Tehát például az integrátor $\mathrm{K}+\mathrm{F}$ szervezetét, bolygóvállalati megrendeléseket végzố csoportját vagy számviteli osztályát kapcsolja össze a bolygóvállalat azonos feladattal megbízott szervezeti egységével vagy - jóval kisebb szervezet lévén - szakemberével.) A szakmaközi csatornák kiépítése azonban még nem biztosíték arra, hogy az operatív irányítás mint rendszer is hatékonyan múködjék az integrátor és bolygóvállalata között. Ezért hoztak létre az integrátor vállalatnál egy új felsővezetói pozíciót a rendszer egészének felügyeletére: a Chief Network Operation Officer (CNOO), a hálózat operatív múködéséért felelős felsố vezető feladata, hogy ellenőrizze, betáplálják-e a szakmaközi csatornákba az elôírt információkat mind az integrátornál, mind a bolygóvállalatnál, hogy megfelelően értékelik-e ezeket 
a partnervállalatnál, hogy sor kerül-e ezután az esetleg szükséges új döntésekre és új intézkedésekre, s hogy mindez időben, pontos adatokkal és az események okainak, valamint feltételeinek közlésével történik-e meg. A CNOO mindezt a második csatornatípus, a rendszerirányító csatorna segítségével ellenőrzi és vezérli, s ezen keresztül épít ki partnerkapcsolatokat a hálózatban múködő összes bolygóvállalat csúcsvezetôjével, vagyis így jön létre az egységes operatív múködés még az igen sokszereplős bolygóvállalati hálózatban is.

\section{Kompatibilis irányítás vevốkörös vállalati kapcsolatban}

Az integrátor három meróben új feltétellel találja szemben magát, ha a hálózat vevôkörös vállalatokkal épül ki (vagyis olyanokkal, amelyek több vevôt is kiszolgálnak). A vevoókörös vállalat

1. többnyire nagyobb, mint a jellegzetes bolygóvállalatok,

2. ezeknél jóval lazábban, kevesebb érdekkel kötődik az integrátorhoz, s végül

3. többnyire az integrátor versenytársaival is üzleti kapcsolatban áll.

Mindezek miatt egy ilyen hálózat összehangolt múködtetése új feladatot jelent az integrátor számára mind az üzleti stratégia, mind a $\mathrm{K}+\mathrm{F}$ és az operatív irányítás területén.

Az üzleti stratégia kérdéskörében (ez az 1. táblázatban a $\mathrm{V}_{\text {strat }}$-tal jelölt tevékenység) az integrátornak azzal a veszéllyel kell számolnia, hogy - maradéktalanul kompatibilis irányítás esetén - még a féltve őrzött információk is kiszivároghatnának vevookörös partnerétôl a versenytársaihoz. Ezért egy ilyen hálózatban az integrátor csak részleges kompatibilitásra törekedhet: csupán azokat a stratégiai céljait szabad egyeztetnie vevókörös partnerével, amelyek széles körú megismerése sem veszélyezteti versenypozícióját. Ebben az esetben viszont magától adódik a kérdés: így miként tárhatja fel az integrátor vevôkörös partnerének véleményét a versenypozícióját veszélyeztető, s ezért fel sem vetett stratégiai témákban (például egy új anyagféleség, új alkatrész vagy új technológia fejlesztésének témájában), hiszen ezek egyeztetése azonnal elárulná a mögöttük álló új és egyelöre még titkolt stratégiai célt? Erre a kérdésre két válasz lehetséges:

- az integrátor több stratégiai variánst is egyeztethet vevőkörös partnerével, s ezzel bizonytalanságban hagyja, hogy késóbb melyik stratégiát fogja megvalósítani,

- a másik megoldás: „kiszervezi” tájékozódását, vagyis nem vevókörös partnerével, hanem a té- mára szakosodott szervezettel (például kutatóintézettel, egyetemi tanszékkel) egyeztet.

De mindkét esetben számolnia kell azzal, hogy vevókörös partnere - szemben a bolygóvállalatokkal - nem készülhet fel az integrátorral egy idôben az új stratégia megvalósítására. A két megoldásnak tehát óhatatlanul az a következménye, hogy az integrátor által elhatározott stratégiamódosítás vagy -váltás csak némi késéssel valósulhat meg. Sôt, a késés igen jelentős is lehet, ha a vevôkörös partnernek nincs a módosításhoz vagy váltáshoz elegendő fejlesztési forrása, ha üzletvitelének csekély a rugalmassága, vagy ha érdektelen a váltásban, mert többi üzleti kapcsolata azt egyáltalán nem sürgeti. Az ilyen jelentős késés kockázatát végül azzal mérsékelheti az integrátor, hogy már jó előre tájékozódik: milyen más, potenciális vevoókörös partnerekkel számolhatna a jövooben, s ezeknek milyen lehetőségük és mekkora érdekük lenne a hálózathoz való csatlakozás? S egy ilyen tájékozódás, ha eredménnyel jár, mindenképpen erősíti az integrátor tárgyalópozícióját meglévő vevoókörös partnerével szemben. Az üzleti stratégia kérdéskörében tehát - a bolygóvállalati hálózat tennivalóival összevetve - elsôsorban ilyen új feladatok várnak az integrátorra.

A kutatás-fejlesztés területén (ez az 1. táblázatban a $\mathrm{V}_{(\mathrm{K}+\mathrm{F})}$-fel jelölt mezó) eleve kizárt az a sokrétú integrátori támogatás, amellyel bolygóvállalatának kutatási és fejlesztési lépéstartását segíti. Vevôkörös vállalat esetében ugyanis éppen versenytársai számára hozna létre ,ingyenes” versenyelőnyt egy ilyen támogatással. A kérdés elméleti megoldása lehetne egy „,vállalatközi licencmegállapodás", amelyik azt tartalmazná, hogy a vevôkörös partner csak az integrátorral végzett tevékenységében hasznosítaná a közös $\mathrm{K}+\mathrm{F}$ eredményét. A gyakorlatban azonban ez aligha múködne: a partnernek nem lenne gazdaságos ugyanarra a célra „kétféle termék” gyártása, vagy „kétféle technológia” alkalmazása, és nagy lenne annak a veszélye is, hogy a termék vagy a technológia kisebb módosításával mégis hozzájutnának az integrátor versenytársai a $\mathrm{K}+\mathrm{F}$,ingyenes” eredményéhez. Ezért célravezetőbb megoldás a $\mathrm{K}+\mathrm{F}$ megvalósítása közös vállalkozásként (,,joint venture”ként): ezt az integrátor és vevôkörös partnere közösen finanszírozhatja, a létrehozott eredmény az integrátor és a vevốkörös partner közös tulajdona, s ezt már közösen szabadalmaztatják az illetékes szabadalmi hivatalokban. A közös vállalkozásnak persze csak akkor van értelme, ha a $\mathrm{K}+\mathrm{F}$ várható ráfordítása és eredménye számottevő: kisebb horderejû́ $\mathrm{K}+\mathrm{F}$ esetében az üzleti stratégiánál ajánlott tájékozódás hozhat megoldást, s ennek eredményeként a rátalálás egy olyan új vevốkörös partnerre, 
amelyik nem az integrátor közvetlen versenytársainak szállít. És ebben az esetben járható útnak túnik az előbb még elvetett „vállalatközi licencmegállapodás” is, hiszen ez már nem meglévő, hanem még csak lehetséges üzleti partnereket zárna ki az ,ingyenes versenyelóny” megszerzésének lehetôségéből.

Az operatív irányítás, tehát az 1 . táblázat $\mathrm{V}_{\mathrm{opir}}$ mezójének vonatkozásában majdnem kizárt, hogy a bolygóvállalati kapcsolat bemutatásánál felsorolt 15 téma egyikében is létrejöjjön igazi kompatibilis irányítás. $\mathrm{Az}$ integrátor ugyanis aligha állhat elố az ott leírt követelményekkel, hiszen csupán egyike a vevókörös partner számos vásárlójának, s ezért nem írhatja elő partnerének operatív feladatait, nem szabályozhatja múködésének folyamatait. (Ilyen előnyt joggal követelhetne magának a partner többi vevôje is.) Ebben az esetben tehát más megoldást kell találnia az integrátornak: a klasszikus kompatibilis irányítás hiányát idôvel, nevezetesen előrelátással és előretartással kompenzálhatja. Vagyis olyan időpontban kell indítania vevókörös partnerének szóló jelzését egy elvárt operatív feladat teljesítésére, hogy az eredmény ugyanakkor álljon a rendelkezésére, mint amikorra azt a maradéktalanul kompatibilis irányítás hozná létre. Ennek azonban három alapvetô feltétele is van:

1. Az integrátornak folyamatosan ismernie kell, hogy mekkora idő́tfutással valósulhatnak meg partnerénél ezek a nem egyeztetett irányítással vezérelt folyamatok. Ehhez pedig folyamatos információs kapcsolatra, „párbeszédre” van szükség az integrátor és partnere között.

2. A vevókörös partnernek kötelezettséget kell vállalnia, hogy a párbeszéd során megadott ütemezést és az együttmúködés egyéb feltételeit szigorúan betartja.

3. Az integrátornak rendelkeznie kell azzal a technikával - különösen akkor, ha az irányítás számítástechnikai segítséggel valósul meg -, amelyik lehetővé teszi a vevókörös partnerrel folytatott párbeszéd inputjainak konvertálását saját rendszerébe.

Valójában ennek a három alapvetô feltételnek a betartása emeli az integrátor és a vevókörös partner operatív irányítási kapcsolatát - a hagyományos üzleti együttmúködésen túl - a hálózat szintjére.

Összegezve mindezeket levonható a következtetés: olyan hálózatban is létrejöhet kompatibilis irányítás, amelyik egy integrátor és számos vevókörös vállalat között épül ki, ám egy ilyen hálózat irányítására - a bolygóvállalatok hálózatával összehasonlítva - merôben más technikákat kell alkalmazni.

\section{Kompatibilis irányítás vegyes szerkezetü rendszerben}

A kompatibilis irányítás feltételeinek és módszereinek áttekintése elóbb egy bolygóvállalatokból, majd egy vevôkörös vállalatokból álló hálózat esetében azt bizonyította, hogy a kétféle hálózat feltételei és módszerei aligha egyeztethetốk össze. Ebből következik, hogy meróben új problémát jelent egy olyan hálózat kompatibilis irányítása, amelyik szerkezete vegyes, vagyis amelyben az integrátor partnerei között vannak bolygóés vevớkörös vállalatok is. Megoldást azonban erre az esetre is kell találni: olyat, amelyben érvényesülhetnek a kompatibilitás elónyei.

Az túnik a leginkább járható útnak, ha az üzleti stratégia kérdésében és a kutatás-fejlesztés témáiban (ezek $\mathrm{VR}_{\text {strat }}$ és $\mathrm{VR}_{(\mathrm{K}+\mathrm{F})}$ jelekkel szerepelnek az 1. táblázatban) az integrátor vállalat vezetése párhuzamos megoldást valósít meg: egyszerre alkalmazza azt a módszert, amely a bolygóvállalatokkal, illetve a vevókörös vállalatokkal kiépült hálózat kompatibilis irányításának bemutatásánál szerepelt. Ilyenkor a két módszer eredményeinek egyeztetése egymással, valamint az integrátor vállalat stratégiai céljaival - az integrátor csúcsvezetôjének, igazgatótanácsának stb. jóváhagyása előtt - a korábban már említett CNOO feladata, beleértve az óhatatlanul szükséges visszacsatolásokat is. Ezzel a többlépéses folyamattal legalábbis megközelíthetố egy maradéktalanul kompatibilis irányítás hatékonysága.

Sajátos problémát jelent viszont a kétféle hálózat mindennapi múkködésének operatív irányítása (tehát az 1. táblázat $\mathrm{VR}_{\mathrm{opir}}$ mezejében jelzett tevékenység). Ennek optimális megoldása lehet a „Hárompólusú kommunikációs rendszer" (HKR) kiépítése. Szervezetében az integrátor CNOO-jának mint a hálózat operatív múködését irányító „,vezérkari fônöknek” két ,adjutánsa” van, akiket nagy hálózatokban két feladatcsapat, „task force" is támogathat. Ôk alkotják a kommunikációs rendszer elsố pólusát. Közülük az egyik ,adjutáns” a vegyes szerkezetú hálózatba tartozó bolygó-, a másik pedig a vevókörös vállalatokkal tartja kapcsolatot: az ezekhez vezetố csatornáknak a múködtetésével gyújti, értékeli, egyezteti, készíti elő döntésre, majd továbbítja döntés után a kompatibilis irányítás információit. A második pólus a bolygó-, illetve vevókörös vállalatokból (esetleg ezek szervezeti egységeiból) áll. Ezeket kommunikációs csatornák kapcsolják az integrátor szervezeti egységeihez (például a beszerzés, a termelésirányítás, a vállalati pénzügyek stb. szervezeteihez). A csatornák feladata a hálózati együttmúködés információáramlásának „rövidre zárása”: segítségükkel valósul meg az információcsere a megrendelésekról, 
a teljesítésekrôl, a számlázásról, a benyújtott számlák kiegyenlítéséról stb. Végül a harmadik pólus az integrátor vállalat szervezeti egységeiból alakul ki. Ezeket kommunikációs csatornák kötik össze a CMOO két „adjutánsával”, s a csatornák azokat az információkat továbbítják, amelyek a szervezeti egységek hálózatot múködtető tevékenységéról szólnak. A hálózat kompatibilis irányításáért felelős „,vezérkari főnök” az így beérkezô információk és az „adjutánsok” összesítései alapján szerezhet tudomást az operatív irányítás folyamatairól (méghozzá nem csupán az információs, hanem a reálfolyamatokról is!), hozhat döntéseket vagy egyeztethet akár az integrátor vállalat csúcsvezetôjével, akár a bolygó- vagy vevốkörös vállalatok vezetôivel. (Azt nem is kell külön hangsúlyozni, hogy a három pólust összekötő csatornák mindegyikében kétirányú az információk áramlása, hiszen ez minden kommunikálás alapfeltétele.)

\section{$* * *$}

Befejezésül érdemes felhívni a figyelmet arra, hogy a vállalati hálózatok kompatibilis irányítása ma már megköveteli a számítástechnika segítségét. Szakembereinek tehát ki kell fejlesztenie azokat a modelleket, amelyek az iparági, a vállalati és a most felvázolt hálózati sajátosságokhoz egyaránt illeszkedve növelik az irányítás pontosságát, felgyorsítják ennek és a hálózat egészének a tevékenységét, és ezzel fokozzák a hatékonyságát. Napjaink egyre élesebb és egyre inkább globálissá táguló versenyében tehát egyre inkább a számítástechnikára alapozott kompatibilis irányítás növelheti jelentôs mértékben a nemzetközi szintú versenyképességet, és nemcsak egy hálózat egészében, hanem az abba beépült valamennyi vállalat számára is.

\section{Felhasznált irodalom}

Anklam, P. (2007): New Work: A Practical Guide to Creating and Sustaining Networks at Work and in the World. Elsevier/Butterworth-Heinemann, XVIII. 268 p.

Bakker, H.D.C. (2004): Next Leap: Achieving Growth through Global Networks, Partnership and Co-operation. Cyan, XX., 204 p.

Beck and al. (2006): Getting Real about Networks: Unlocking Corporate Knowledge Assets. Palgrave Macmillan, XII. $256 \mathrm{p}$.

Benkler, Y. (2006): Wealth and Networks: How Social Production Transforms Markets and Freedom. Yale University Press, XII., 515 p.

Bloomfield, B.P. (1997): Information Technology and Organization: Strategies, Networks and Integration. Oxford University Press, VIII., 186 p.
Ciccarelli, P. (2004): Networking Foundations. SYBEX, $\mathrm{XV} ., 351 \mathrm{p}$.

Child, J. (2005): Corporate Strategy: Managing Alliances, Networks and Joint Ventures. Oxford University Press, XII., 457 p.

Cool, K. (2005): Restructuring Strategy: New Networks and Industry Challenges. Blackwell, X., 299 p.

Darkow, I. (2007): Innovation Management in Global Networks: Challenge and Chance. Springer.

Derfler, F.J. (2004): How Networks Work. Que, VI., 233 p.

Dyer, J.H. (2000): Collaborative Advantage: Winning through Extended Enterprise Supplier Networks. Oxford University Press, XII., 209 p.

Ebers, M. (1997): Formation of Inter-organizational Networks. Oxford University Press, VIII., 295 p.

Fitzgerald, J. (2004): Business Data Communication and Networking. Wiley, XIV., 546 p.

Forsgren, M. (1992): Managing Networks in International Business. Gordon and Breach Science Publ. XVIII., 254 p.

Gemunden, H.G. (1998): Relationships and Networks in International Markets. Pergamon Press, XVIII., 460 p.

Gilbert, N. (2007): Strategic Networks: Learning to Compete. Blackwell, XVII., 197 p.

Goold, M. (2002): Designing Effective Organizations: How to Create Structured Networks. Jossey-Bass, XII., 356 p.

Hoványi G. (2008): A tudás és a nemzetközi tudásháló szerepe egy régió iparának fejlődésében. Európai Tükör (Megjelenés alatt.)

Iacobucci, D. (1996): Networks in Marketing. Sage, XX., $442 \mathrm{p}$.

Nooteboom, B. (2004): Inter-firm Collaboration, Learning and Networks: An Integrated Approach. Routledge, IX., $230 \mathrm{p}$.

Murthy, C.S.M. (2001): Resource Management in Red-time Systems and Neworks. MIT Press, XIV., 405 p.

Perri, G. (2006): Managing Networks of Twenti-first Century Organizations. Palgrave Macmillan, XIV., 309 p.

Pervez, N.C. (2005): Managing Opportunity Development in Business Networks. Palgrave Macmillan, XI., 346 p.

Pyka, A. (2002): Innovation Networks: Theory and Practice. Edward Elgar, XIII., 232 p.

Rugman, A.M. (2000): Multinationals as Flagship Firms: Regional Business Networks. Oxford University Press, XII., 219 p.

Sheldon, T. (1994): LAN Times Encyclopaedia of Networking. Osborn McGraw-Hill, XXXII., 1006 p.

Toumi, I. (2002): Networks of Innovation: Change and Meaning in the Age of the Internet. Oxford University Press, XI., $251 \mathrm{p}$.

Zheng, L. (2002): Strategic Production Networks. Springer Verl. XV., 489 p.

Cikk beérkezett: 2007. 10. hó

Lektori vélemény alapján átdolgozva: 2008. 3. hó 